\section{Negative Pressure Irrigation Presents Mineralizing Potential in Dogs' Immature Teeth with Periapical Lesion}

Léa Assed Bezerra da Silva ${ }^{1} \mathbb{D}$, Marcela Lopes Linhares ${ }^{2} \mathbb{B}^{\circ}$, Raquel Assed Bezerra da Silva ${ }^{1} \mathbb{D}$, Paulo Nelson-Filho ${ }^{1} \mathbb{C}$, Marilia Pacífico Lucisano ${ }^{1} \mathbb{C}_{\text {, }}$ Carolina Maschietto Pucinelli ${ }^{1}$, Fabrício Kitazono de Carvalho ${ }^{1}$,, Nestor Cohenca $^{3}$ (D)
'Department of Pediatric Clinics, School of Dentistry of Ribeirão Preto, USP - Universidade de São Paulo, Ribeirão Preto, SP, Brazil

${ }^{2}$ Department of Dentistry, UEA - Universidade do Estado do Amazonas, Manaus, AM, Brazil ${ }^{3}$ Department of Pediatric Dentistry, University of Washington and Private Practice Limited to Endodontics in Everett WA, USA

Correspondence: Dra. Marília Pacífico Lucisano, Avenida do Café $\mathrm{s} / \mathrm{n}$, 14040-904 Ribeirão Preto, SP, Brasil. Tel: +55-16-3315-4143. e-mail: marilia.lucisano@forp.usp.br
The objective of this in vivo study was to assess the effect of the root canal irrigation by negative and positive apical pressure on the expression of molecules that are an indicative of cell differentiation with mineralizing phenotype in teeth of dogs with incomplete rhizogenesis and induced periapical lesion. A total of 30 teeth (60 roots) were distributed into 3 groups $(n=20)$ : EndoVac ${ }^{\circledR}$, Conventional and Control. After 90 days, the routine histotechnical procedures were performed and the sections were submitted to immunohistochemical technique for the staining of osteopontin (OPN), alkaline phosphatase (ALP) and the RUNX2 transcription factor in the apical and periapical regions of the roots. A semi-quantitative analysis of the positive immunostaining was performed and the intensity of the expression was classified in absent (0), mild (1), moderate (2), or intense (3). Scores data were statistically analyzed by the Kruskal-Wallis non-parametric test and Dunn post-test, and the significance level was set at 5\%. RUNX2 immunostaining revealed that in the negative pressure group there was a significantly stronger $(p<0.05)$ immunostaining in comparison to the control group. Regarding the OPN expression, it was not possible to detect a statistically significant difference between the groups ( $p>0.05)$. After analyzing ALP immunostaining, a statistically significant difference was observed between the groups $(p<0.05)$, and the negative pressure group showed a markedly stronger mark immunostaining than the control group. The results of the present in vivo study allowed concluding that negative apical pressure irrigation presents mineralizing potential in immature teeth with apical periodontitis.
Key Words: negative pressure irrigation, immunohistochemistry, mineralization, periapical lesion, immature teeth, repair.

\section{Introduction}

Teeth with incomplete rhizogenesis have peculiar anatomical characteristics that make it difficult to perform several steps of endodontic treatment, such as the elimination of infection, risk of extrusion of irrigating solution and necrotic material to the periapical region, and the possibility of overfilling and incomplete apical sealing $(1,2)$.

Some studies demonstrated that the use of the negative pressure irrigation system is more efficient for the removal of the debris and the smear layer, mainly of the apical third, prevents the extrusion of irrigating solution to the periapical region and presents a better cleaning ability of the root canal system (3-7).

Revascularization procedures have been proposed for the treatment of permanent teeth with pulp necrosis and incomplete root development (8-10), as well as for teeth with closed apex (11). The potential of inducing tissue repair provided by negative pressure irrigation system was showed by Silva et al. (12) and Pucinelli et al. (13). These studies were conducted on dogs' teeth with incomplete root development and periapical lesion and demonstrated that the wide apical opening was filled by a well-structured matrix of dense connective tissue, rich in young fibroblasts and neo-formed blood vessels, which invaginated themselves into the interior of the root canal, promoting a phenomenon similar to revascularization. This tissue of periodontal origin, in many cases, was in different stages of mineralization, exhibiting varied morphologies.

The objective of this in vivo study was to assess the effect of the root canal irrigation by negative and positive apical pressure on the expression of molecules that are an indicative of cell differentiation with mineralizing phenotype in teeth of dogs with incomplete rhizogenesis and induced periapical lesion.

The null hypothesis tested was that there is no difference in the mineralizing potential between negative and positive apical pressure irrigation systems.

\section{Material and Methods}

The histological sections used in this study were obtained from the slide bank of the Department of Pediatric Dentistry of the School of Dentistry of Ribeirão Preto. The study was approved by the Institutional Ethics Committee on Animal Research (\#006/2012) and was carried out based on the protocols recommended by International Organizational 
Standardization (ISO 7405:2008) (14). Seventy-two slides from premolars of three Beagle dogs at 4 months of age were evaluated. A total of 30 teeth (60 roots) were distributed into 3 groups $(n=20)$ : EndoVac ${ }^{\circledR}$ Group - Irrigation with negative apical pressure; Conventional Group - Irrigation with positive apical pressure; and Control Group - Periapical lesion without treatment. Methodological details can be found in the study of Silva et al. (12) and Pucinelli et al. (13).

Briefly, the animals were pre-anesthetized and anesthetized with an endovenous injection of Neozine (Aventis Pharma Ltda., São Paulo, SP, Brazil; 1 mg/kg body weight) and tiletamine hydrochloride/zolazepam hydrochloride (Zoletil 50; Virbac do Brasil Ind. e Com. Ltda., São Paulo, SP, Brazil; $0.1 \mathrm{~mL} / \mathrm{kg}$ body weight), respectively. Inhalation anesthesia with Isoflurane (Abbott Laboratories Ltd., St. Laurent, Quebec, Canada) was delivered using an inhalation anesthesia apparatus (Takaoka KT-20; Takaoka Indústria e Comércio Ltda., São Paulo, SP, Brazil) and throughout the duration of the operative procedures, the animals were maintained on isotonic saline solution (0.9\% $\mathrm{NaCl})$ (Glicolabor Indústria Farmacêutica Ltda., Ribeirão Preto, SP, Brazil).

Coronal access was performed with spherical and tapered diamond burs (K.G. Sorensen, São Paulo, SP, Brazil) under copious water cooling. After pulp removal, the root canals were left exposed to the oral cavity for 7 days to allow microbial contamination and were sealed with zinc oxide-eugenol cement (SS White, Rio de Janeiro, RJ, Brazil) in order to induce apical periodontitis, that occured after 15 to 25 days.

After this period, teeth from Endovac and Conventional groups were isolated with rubber dam, the temporary restoration was removed and the following procedures were perfomed: root canal disinfection $3 \mathrm{~mm}$ shorter than the radiographic apex; working lenght determination $(1 \mathrm{~mm}$ shorter than the radiographic apex); root canal preparation with $\mathrm{K}$-file, under irrigation with $10 \mathrm{~mL}$ of $\mathrm{NaOCl} 2.5 \%$ for both the negative pressure irrigation and conventional systems.

After using irrigation system protocols, root canals were irrigated with saline solution, dried with absorbent paper points and sealed with ProRoot MTA (Dentsply Tulsa Dental, Johnson City, TN, USA) and silver amalgam (Sybraloy, Kerr Corporation, Orange, CA, USA).

After 90 days, the animals were euthanized with an intravenous overdose of sodium pentobarbital. The maxillas and mandibles with teeth were dissected and sectioned to obtain individual roots. The routine histotechnical procedures were performed.

\section{Immunohistochemistry}

The slides containing the sections were submitted to immunohistochemical reactions by the immunoperoxidase technique for staining of mineralization related molecules, such as runt-related transcription factor (RUNX-2), osteopontin (OPN), and alkaline phosphatase (ALP). The technique was performed as described by Daltoé et al. (15).

The analysis was performed under Axio Imager.M1 microscope (Carl Zeiss Microlmaging GmbH, Göttingen, Germany), coupled to an Axiocam MRc5 camera, by an experienced examiner, calibrated and blinded to the groups under a conventional light. A semi-quantitative analysis of the positive immunostaining for RUNX-2, OPN and ALP was performed in a magnification of 20X in two counting frames of approximately $1 \mathrm{~mm}^{2}$ : in the apical third of the root and in the periapical region. An experienced blind examiner evaluated all slides and the intensity of the expression of these markers was classified according to the following scores: (0) absent; (1) mild; (2) moderate; or (3) intense.

The score system was based and adapted from a two-grade scale of staining level used in previous medical studies $(16,17)$. Then, in the present study, as the immunohistochemical staining was scored semi-quantitatively based on the intensity of diffuse immunoreaction as following: (0) absent- no staining; (1) mild- low and weak diffuse staining; (2) moderatemoderate diffuse staining; and (3) intense- high and strong diffuse staining.

Data were transformed into percent and the groups compared to each other.

\section{Statistical Analysis}

The data were submitted to the verification of the normality by the Shapiro-Wilk test. Then, the KruskalWallis non-parametric test and Dunn's post-test were used to compare the data, using Graph Pad Prism 6.0 (Graph Pad Software Inc, San Diego, CA, USA). All analyzes were performed with a significance level of $5 \%$.

\section{Results}

The statistical analysis after the evaluation of the immunostaining for RUNX2 revealed that in the negative pressure irrigation system group there was significantly more intensely immunostaining ( $p=0.03)$, in comparison to the control group. In percentage and considering the intensity of the positive staining for RUNX2 as absent, mild, moderate and intense, the following results were obtained, respectively: $0 \%, 75 \%, 25 \%$ and $0 \%$ for the control group; $0 \%, 25 \%, 62,5 \%$ and $12,5 \%$ for the conventional irrigation; and $0 \%, 25 \%, 25 \%$ and $50 \%$ for the negative pressure irrigation system. Figure 1 illustrates the representative immunostaining for the RUNX-2 of each group.

Regarding the evaluation of the OPN immunostaining, it was not possible to observe a statistically significant 
difference between the groups $(p=0.15)$. In percentage and considering the intensity of the positive staining for OPN as absent, mild, moderate and intense, the following results were obtained, respectively: $0 \%, 50 \%, 37,5 \%$ and $12,5 \%$ for the control group; $0 \%, 12,5 \%, 62,5 \%$ and $25 \%$ for the conventional irrigation; and $0 \%, 50 \%, 50 \%$ and $0 \%$ for the negative pressure irrigation. Figure 2 shows representative OPN immunostaining of each group. Although in the images it could be observed a more intense immunostaining in the negative pressure irrigation group, the statistical analysis did not show difference between the groups.

After analysis of the immunostaining for ALP, there was a statistically significant difference between the groups $(p=0.0021)$, and the negative pressure group showed significantly more intense staining than the control group. As a percentage, considering the staining of ALP as absent, mild, moderate and intense, the following results were obtained, respectively: $75 \%, 12,5 \%, 12,5 \%$ and $0 \%$ for the control group; $0 \%, 85,7 \%, 14,3 \%$ and $0 \%$ for the conventional irrigation; and $0 \%, 14,3 \%, 85,7 \%$ and $0 \%$ for the group treated with the negative pressure irrigation system. It should be noted that the immunostaining for ALP was concentrated in the region of the bone around the periapical lesion, as can be observed in the images of Figure 3.
Table 1 presents the statistical results and the percentage of each score attributed to specimens of the Control Group - Periapical lesion without treatment, Conventional Group - Irrigation with positive apical pressure and EndoVac ${ }^{\circledR}$ Group - Irrigation with negative apical pressure, after immunostaining for RUNX-2, OPN and ALP.

\section{Discussion}

Considering the difference in the mineralizing potential between negative and positive apical pressure irrigation systems, the null hypothesis should be rejected.

Traditionally, the endodontic treatment of immature permanent teeth with pulp necrosis consists of the stimulation of the apical closure by intracanal dressings with calcium hydroxide-based pastes $(1,2,12,18)$. However, until ideal anatomical conditions can be obtained to allow root canal filling, several months may be required (2). Also, this conventional treatment protocol may compromise the functionality and long-term prognosis of the involved tooth, since it will present an intrinsically weakened root structure (19).

Thus, alternative methods have been proposed, such as revascularization procedures, increasing the therapeutic possibilities for immature teeth with pulp necrosis. These current approaches allow the walls of the canal to become
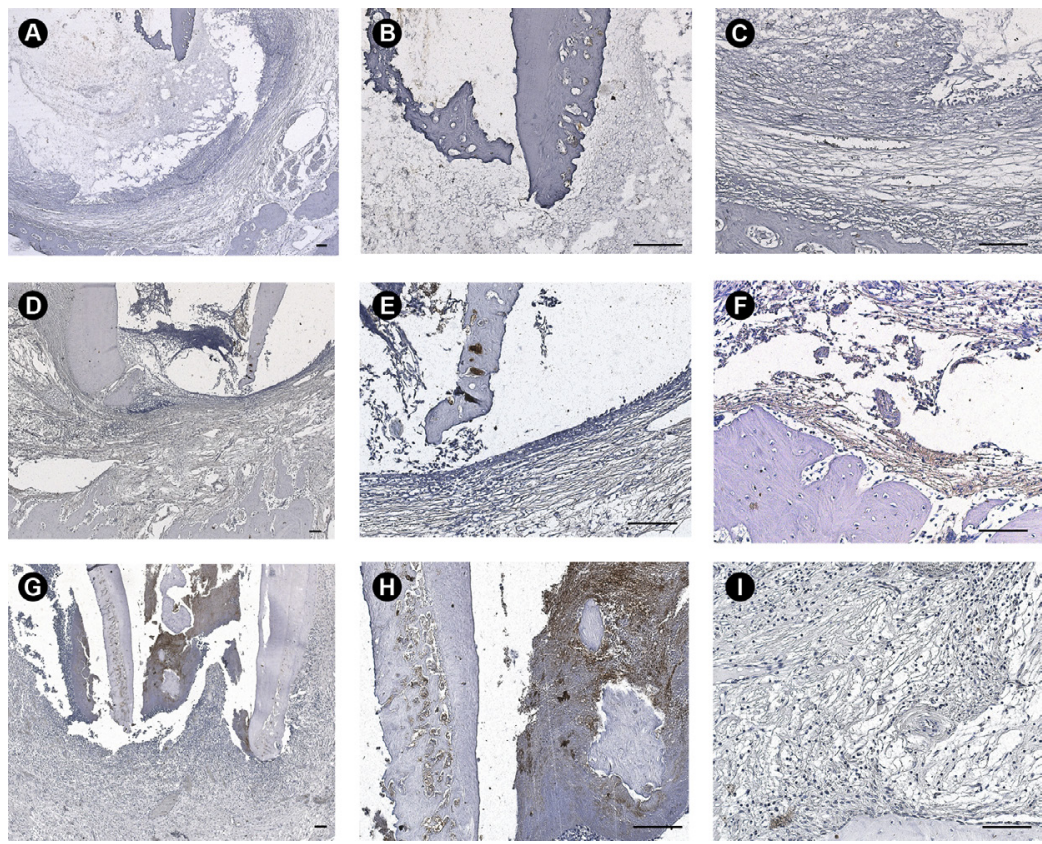

Figure 1. Photomicrographs of the immunostaining for the runt-related transcription factor (RUNX-2) in the different groups. (A) Panoramic view of the specimen from the Control group demonstrating very discrete marking for RUNX2. (B) Magnification of Figure A, evidencing mild RUNX2 staining on cemental lacunae. (C) Magnification of Figure A, evidencing absence of RUNX2 staining on periapical lesion and adjacent alveolar bone. (D) Panoramic view of the specimen of the Conventional group demonstrating moderate staining for RUNX2, evidenced in a larger magnifications in the images $\mathrm{E}$ and $\mathrm{F}$, where concentrated staining is observed in cemental lacunae and close to the alveolar bone. (G) Panoramic view of the negative pressure group specimen showing more intense immunostaining. The image $(\mathrm{H})$ demonstrates in greater magnification the intense RUNX2 staining in cemental lacunae and in the tissue formed inside the root canal. (I) Magnification of Figure G, where a discrete immunostaining is observed close to the alveolar bone. Scale bar $=0.1 \mathrm{~mm}$. 

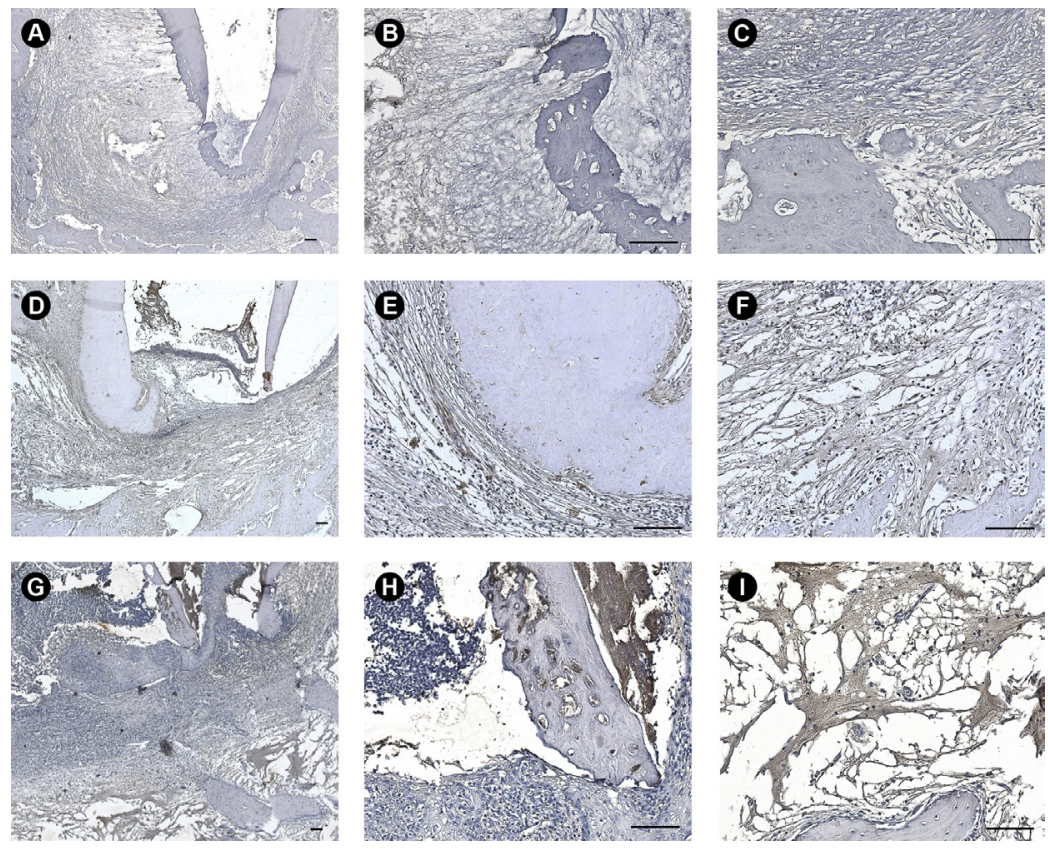

Figure 2. Photomicrographs of the immunostaining for Osteopontin (OPN) in the different groups. (A) Panoramic view of the Control group specimen showing mild staining for OPN. (B) Magnification of Figure A, showing mild OPN staining on the periapical lesion close to the apical cementum and in some cemental lacunae. (C) Magnification of Figure A, showing absence of OPN staining on periapical lesion close to the alveolar bone. (D) Panoramic view of the specimen of the Conventional group demonstrating moderate staining for OPN. (E) Detail of the previous image, evidencing moderate staining on the periapical lesion next to the apical cementum. (F) Magnification of Figure D, evidencing weak diffuse staining on the periapical lesion next to the alveolar bone. (G) Panoramic view of the negative pressure group specimen demonstrating moderate greater magnification in the image (H). (I) Magnification of Figure G, evidencing moderate diffuse staining on the periapical lesion next to the alveolar bone. Scale bar $=0.1 \mathrm{~mm}$.
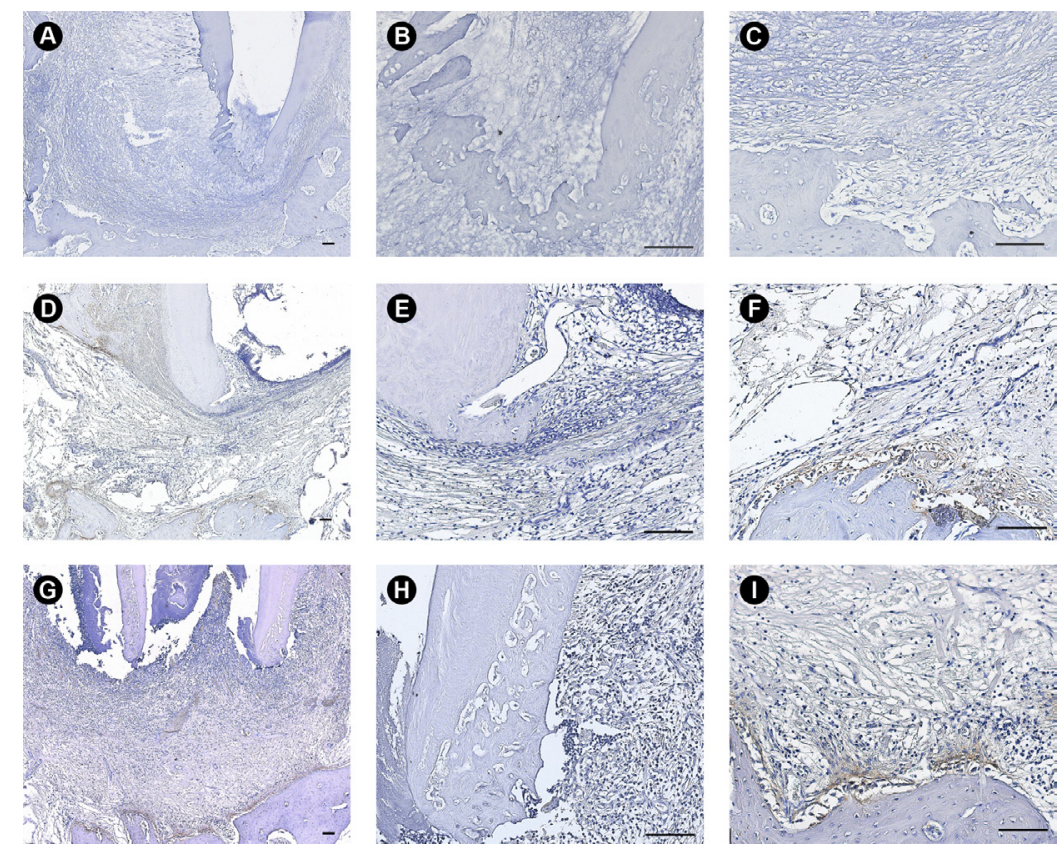

Figure 3. Photomicrographs of the immunostaining for Alkaline Phosphatase (ALP) in the different groups. (A) Panoramic view of the specimen of the Control group evidencing the absence of staining for ALP, as evidenced in greater magnifications in the images (B) e (C). (D) Panoramic view of the Conventional group specimen demonstrating mild staining for ALP. (E) Magnification of Figure D, evidencing absence of ALP staining in apical cement and adjacency. (F) Detail of the image D, evidencing mild staining of ALP concentrated in the region next to the alveolar bone. (G) Panoramic view of the negative pressure group specimen demonstrating moderate ALP immunostaining, concentrated in the alveolar bone region around the periapical lesion, as evidenced by a larger magnification in Figure (I). (H) Magnification of Figure G, evidencing absence of ALP staining in apical cement and adjacency. Scale bar $=0.1 \mathrm{~mm}$. 
more resistant and reinforced and it enables the continuity of the root development $(9,10)$. The ideal treatment response would be the formation of connective tissue pulp within the canal (12). However, studies have shown that the tissue formed after the revascularization procedure has periodontal origin, presenting cementogenic, periodontal and bone nature $(11,20)$.

It should be emphasized that the present in vivo study was focused on evaluating the effect of irrigation system on the periapical expression of mineralizing molecules. Then, only a correlation with the revascularization process could be performed, with respect to the induction of repair mineralized tissue at the apical level. To follow the revascularization protocol, it would be necessary to use $\mathrm{NaOCl} 1.5 \%$ as irrigating solution, an intracanal dressing with calcium hydroxide or triantibiotic paste between sessions and, after controlling the infection, to induce apical slight bleeding. In this study, the irrigation was performed with $\mathrm{NaOCl} 2.5 \%$ solution, as used in previous studies for teeth with apical periodontitis (10-13).

The mechanisms involved in periodontal repair and continuity of root development in permanent teeth with incomplete rhizogenesis and periapical lesion are not completely elucidated (10). The strategies to promote the

Table 1. Summary of the percentage of each score for each group, with the statistical results

\begin{tabular}{|c|c|c|c|}
\hline & RUNX2 & OPN & ALP \\
\hline \multirow{4}{*}{$\begin{array}{l}\text { Control Group - } \\
\text { Periapical lesion } \\
\text { without treatment }\end{array}$} & $0(0) a$ & $0(0) \mathrm{a}$ & $0(75 \%) \mathrm{a}$ \\
\hline & $1(75.0 \%)$ & $1(50.0 \%)$ & $1(12.5 \%)$ \\
\hline & $2(25.0 \%)$ & $2(37.5 \%)$ & $2(12.5 \%)$ \\
\hline & $3(0)$ & $3(12.5 \%)$ & $3(0)$ \\
\hline \multirow{4}{*}{$\begin{array}{l}\text { Conventional } \\
\text { Group - Irrigation } \\
\text { with positive } \\
\text { apical pressure }\end{array}$} & 0 (0)ab & $0(0) \mathrm{a}$ & 0 (0)ab \\
\hline & $1(25 \%)$ & $1(12.5 \%)$ & $1(85.7 \%)$ \\
\hline & $2(62.5 \%)$ & $2(62.5 \%)$ & $2(14.3 \%)$ \\
\hline & $3(12.5 \%)$ & $3(25 \%)$ & $3(0)$ \\
\hline \multirow{4}{*}{$\begin{array}{l}\text { EndoVac }{ }^{\circledR} \text { Group } \\
\text { - Irrigation with } \\
\text { negative apical } \\
\text { pressure }\end{array}$} & $0(0) b$ & $0(0) \mathrm{a}$ & $0(0) b$ \\
\hline & $1(25.0 \%)$ & $1(50.0 \%)$ & $1(14.3 \%)$ \\
\hline & $2(25.0 \%)$ & $2(50.0 \%)$ & $2(85.7 \%)$ \\
\hline & $3(50.0 \%)$ & $3(0)$ & $3(0)$ \\
\hline${ }^{*} \mathrm{p}$ value & 0.03 & 0.15 & 0.0021 \\
\hline
\end{tabular}

* According to Kruskal-Wallis test and Dunn's post-test. Different letters mean statistical difference $(\mathrm{p}<0.05)$. growth of new tissues within the pulp space are based on 4 fundamental concepts: 1 - Effective elimination of endodontic infection; 2 - Recruitment of mesenchymal stem cells of the apical region; 3 - Creation of a scaffolf that allows the growth of a new tissue and; 4 - Appropriate coronary sealing to prevent re-infection (10).

The present study evaluated the process of mineralized tissue formation at the apical level after the use of the negative pressure irrigation system during the endodontic treatment of immature permanent teeth periapical lesion. The chemicalmechanical preparation has as primary objective to eliminate the infection of the root canals system, being a fundamental step of the endodontic treatment (21). However, during the use of endodontic instruments and irrigation solution, organic and inorganic debris, bacteria and irrigating solution can be extruded, exacerbating the periapical pathological condition (22). It is known that the larger the apical diameter of the teeth, the higher the risk of damage to the periapical tissues (23). As consistently evidenced, the negative pressure irrigation system considerably reduces the inadvertent apical extrusion of debris and irrigation solution $(24,25)$, emphasizing the biologically beneficial effects of its use in immature teeth. As an additional advantage, there is a better removal of the smear layer and necrotic material from the apical third of the canal lesion $(5,6,26)$, considered the most heavily contaminated region, especially in the presence of periapical lesion.

Agreeing with previous studies $(12,13,26)$ this system promotes an adequate cleaning and disinfection of the root canal system and creates conditions to the occurrence of the repair process. These findings are based on the fact that the cellular, molecular and biochemical mechanisms involved in tissue repair are stimulated by creating a favorable microenvironment. Migration, proliferation, and cell differentiation, as well as matrix deposition and maturation, essential for the connective tissue formation, occur only in the presence of the control of the infectious process.

Induction of bleeding by the over-instrumentation in the apical region has been the step performed during the revascularization procedure to form a blood clot, producing a scaffold within the canal $(1,10)$ and constituting a source of viable cells, which are derived from local circulation, cementum, periodontal ligament or alveolar bone (27).

In addition to addressing the first concept of endodontic infection elimination, negative pressure irrigation also seems to fulfill the functions of recruiting undifferentiated mesenchymal cells from the apical region and creating a scaffold, fundamental for the induction of tissue neoformation. The kinetics of the irrigating solution inside the root canal, assuring volume and cleaning up to 
the working length, allows the wide apical opening to be filled by a blood clot, with the advantage of not causing aggression to the periapical tissues.

Given the above, it is reasonable to suggest that the following situation is provided by the use of negative pressure irrigation: reduced microbial contamination and consequent control of the immunoinflammatory response, induction of the repair process and of tissue neoformation within the root canal. This formed tissue has exhibited various stages of mineralization, which invaginates within the root canal, providing an apical biological sealing $(12,13)$.

Thus, it is justified the relevance of the present study that evaluated the mechanisms involved in the mineralization process after the use of negative pressure system. Significantly more intense expression of the RUNX2 and ALP markers compared to the control grup reveals the mineralizing potential of this system. The RUNX2 has been related to bone and dental mineralization and plays a crucial role in the differentiation of osteoblasts and the homeostasis of mineralized tissues (15). The ALP acts on the initial stage of mineralization, being expressed in the first stages of the differentiation of osteoblasts and odontoblasts and provides the inorganic phosphate to form hydroxyapatite (28). Its role in periapical repair can be confirmed by our results, which demonstrated the expression of this protein concentrated near to the alveolar bone adjacent to the periapical lesion.

Given the more intense expression of RUNX2 and ALP and considering the role in the osteoblastic differentiation of these two markers, a correlation can be made with the study of Pucinelli et al. (13), in which a significantly lower number of osteoclasts were observed in the negative pressure group. At the same time, these results suggest tissue repair at a more advanced stage, agreeing with previous findings $(12,13)$.

Although without a statistical difference with the other groups, the expression of OPN in specimens subjected to negative pressure irrigation corroborates and confirms its repair potential. This extracellular matrix glycoprotein participates in the maintenance or reconfiguration of tissue integrity during inflammatory processes (29), confirming the importance of its expression in tissues.

In addition to the formation of a scaffold rich in undifferentiated mesenchymal stem cells, the presence of signaling molecules is essential elements for the generation of functional tissue (20). The identification of the expression of the RUNX2, ALP and OPN markers in the group treated by the negative pressure irrigation system demonstrates biological relevance, confirming the reparative and mineralizing potential of this system.

It is highlighted that the present findings must be exercised with caution and not transferred directly to clinical conditions because of obvious limitations of immunohistochemical analysis and studies in animals. Regarding the semi-quantitative analysis, the score system was used as in several previous published studies $(15,30,31)$. Also, most of evaluated molecules (ALP and OPN) are extracellular proteins, making it difficult to perform a counting of immunolabelled cells.

Future studies in this area will not only shed new light on understanding signaling pathways involved in mineralization process provided by the negative pressure irrigation system, but also provide a solid foundation for its clinical application. The possibility of using different irrigation solutions, as chlorhexidine, in these further studies should be considered in order to improve the present findings.

Based on the methodological conditions and results of the present study, it is possible to conclude that, despite the numerical tendency for better results, negative pressure irrigation induces the expression of molecules with mineralizing phenotype in the apical region of immature teeth with periapical lesion similarly to the conventional irrigation system.

\section{Resumo}

0 objetivo do presente estudo in vivo foi avaliar o efeito da irrigação do canal radicular por pressão apical negativa e por pressão positiva na expressão de moléculas que são indicativas de diferenciação celular com fenótipo mineralizador em dentes de cães com rizogênese incompleta e lesão periapical. Um total de 30 dentes (60 raizes) foi distribuido em 3 grupos $(n=20)$ : EndoVac, Convencional e Controle. Após 30 dias, foram realizados os procedimentos histotécnicos de rotina e os cortes foram submetidos à técnica de imunohistoquímica para marcação de Osteopontina (OPN), Fosfatase Alcalina (ALP) e para o fator de transcrição RUNX2 nas regiões apical e periapical das raizes. Foi realizada uma análise semi-quantitativa da imunomarcação positiva e a intensidade da expressão foi classificada em ausente (0), leve (1), moderada (2) ou intensa (3). Os dados por escores foram analisados estatisticamente pelo teste não-paramétrico de Kruskal-Wallis e pelo pós-teste de Dunn, e o nivel de significância adotado foi de 5\%. A imunumarcação para RUNX2 revelou que no grupo pessão negativa houve marcação significativamente mais intensa $(p<0,05)$, em comparação ao grupo controle. Com relação à expressão de OPN, não foi possivel observer diferença estatisticamente significante entre os grupos $(p>0,05)$. Após análise da imunomarcação para $A L P$, foi observado diferença estatisticamente significante entre os grupos $(p<0,05)$, e o grupo pressão negativa demonstrou uma marcação siginificativamente mais intensa do que o grupo controle. Os resultados do presente estudo in vivo permitiram concluir que a irrigação por pressão apical negativa apresenta potencial mineralizador em dentes com ápice aberto e lesão periapical.

\section{Rerefences}

1. Lin J, Zeng Q, Wei X, Zhao W, Cui M, Gu J, et al. Regenerative Endodontics Versus Apexification in Immature Permanent Teeth with Apical Periodontitis: A Prospective Randomized Controlled Study. J Endod 2017;43:1821-1827.

2. Silva LAB, Paula-Silva FWG, de Queiroz AM. Tratamiento endodontico de dientes permanentes con rizogénesis incomplete. In: Tratado de Odontopediatría. Segunda Edición. Ed. Amolca. 2018.

3. Fukumoto Y, Kikuchi I, Yoshioka T, Kobayashi C, Suda H. An ex 
vivo evaluation of a new root canal irrigation technique with intracanal aspiration. Int Endod J 2006;39:93-99.

4. Tanomaru-Filho M, Miano LM, Chávez-Andrade GM, Torres FF, Leonardo Rde T, Guerreiro-Tanomaru JM. Cleaning of Root Canal System by Different Irrigation Methods. J Contemp Dent Pract 2015;16:859-863.

5. Karade P, Chopade R, Patil S, Hoshing U, Rao M, Rane N, Chopade $A$, et al. Efficiency of Different Endodontic Irrigation and Activation Systems in Removal of the Smear Layer: A Scanning Electron Microscopy Study. Iran Endod J 2017;12:414-418.

6. Suman S, Verma P, Prakash-Tikku A, Bains R, Kumar-Shakya V. A Comparative Evaluation of Smear Layer Removal Using Apical Negative Pressure (EndoVac), Sonic Irrigation (EndoActivator) and Er:YAG laser -An In vitro SEM Study. J Clin Exp Dent 2017;9:e981-e987.

7. Mancini M, Cerroni L, Iorio L, Dall'Asta L, Cianconi L. FESEM evaluation of smear layer removal using different irrigant activation methods (EndoActivator, EndoVac, PUI and LAI). An in vitro study. Clin Oral Investig 2018;22:993-999.

8. American Academy of Pediatric Dentistry (AAPD). Guideline on Pulp Therapy for Primary and Immature Permanent Teeth. Reference Manual 2016/2017;38:280-288.

9. Hargreaves KM, Diogenes A, Teixeira FB. Treatment options: biological basis of regenerative endodontic procedures. Pediatr Dent 2013;35:129-410.

10. Palma PJ, Ramos JC, Martins JB, Diogenes A, Figueiredo MH, Ferreira P, et al. Histologic Evaluation of Regenerative Endodontic Procedures with the Use of Chitosan Scaffolds in Immature Dog Teeth with Apical Periodontitis. J Endod 2017;43:1279-1287.

11. Gomes-Filho JE, Duarte PC, Ervolino E, Mogami Bomfim SR, Xavier Abimussi CJ, Mota da Silva Santos L, et al. Histologic characterization of engineered tissues in the canal space of closedapex teeth with apical periodontitis. J Endod 2013;39:1549-1556.

12. da Silva LA, Nelson-Filho P, da Silva RA, Flores DS, Heilborn C, Johnson JD, et al. Revascularization and periapical repair after endodontic treatment using apical negative pressure irrigation versus conventional irrigation plus triantibiotic intracanal dressing in dogs' teeth with apical periodontitis. Oral Surg Oral Med Oral Pathol Oral Radiol Endod 2010;109:779-787.

13. Pucinelli CM, Silva LABD, Cohenca N, Romualdo PC, Silva RABD, Consolaro A, et al. Apical Negative Pressure irrigation presents tissue compatibility in immature teeth. J Appl Oral Sci 2017;25:612-619.

14. ISSO. Evaluation of biocompatibility of medical devices used in dentistry. Switzerland. 2008.

15. Daltoé MO, Paula-Silva FW, Faccioli LH, Gatón-Hernández PM, De Rossi A, Bezerra Silva LA. Expression of Mineralization Markers during Pulp Response to Biodentine and Mineral Trioxide Aggregate. J Endod 2016;42:596-603.

16. Capper D, Weissert S, Balss J, Habel A, Meyer J, Jäger D, et al. Characterization of R132H mutation-specific IDH1 antibody binding in brain tumors. Brain Pathol 2010;20:245-254.

17. Cai J, Zhu P, Zhang C, Li Q, Wang Z, Li G, Wang G, et al. Detection of ATRX and IDH1-R132H immunohistochemistry in the progression of 211 paired gliomas. Oncotarget 2016;7:16384-
16395.

18. Rafter M. Apexification: a review. Dent Traumatol 2005;21:1-8.

19. Namour M, Theys S. Pulp revascularization of immature permanent teeth: a review of the literature and a proposal of a new clinical protocol. ScientificWorldJournal 2014;2014:737503.

20. Yang J, Yuan G, Chen Z. Pulp Regeneration: Current Approaches and Future Challenges. Front Physiol 2016;7:58.

21. Desai, Himel. Comparative safety of various intracanal irrigation systems. J Endod 2009;35:545-549.

22. Barbosa-Ribeiro M, Arruda-Vasconcelos R, Fabretti FL, Silva EJNL, De-Deus G, Gomes BPFA. Evaluation of Apically Extruded Debris Using Positive and Negative Pressure Irrigation Systems in Association with Different Irrigants. Braz Dent J 2018;29:184188.

23. Aksel H, Askerbeyli S, Canbazoglu C, Serper A. Effect of needle insertion depth and apical diameter on irrigant extrusion in simulated immature permanent teeth. Braz Oral Res 2014;28:1-6.

24. Azim AA, Aksel H, Margaret Jefferson M, Huang GT. Comparison of sodium hypochlorite extrusion by five irrigation systems using an artificial root socket model and a quantitative chemical method. Clin Oral Investig 2018;22:1055-1061.

25. Venumbaka NR, Baskaran P, Mungara J, Chenchugopal M, Elangovan A, Vijayakumar P. Comparative Evaluation of Endovac and Conventional Irrigating Syringe on Apical Extrusion in Primary Molars. An in vitro Study. J Clin Pediatr Dent 2018;42:355-360.

26. Versiani MA, Alves FR, Andrade-Junior CV, Marceliano-Alves MF, Provenzano JC, Rôças IN, et al. Micro-CT evaluation of the efficacy of hard-tissue removal from the root canal and isthmus area by positive and negative pressure irrigation systems. Int Endod J 2016;49:1079-1087.

27. Ostby BN. The role of the blood clot in endodontic therapy. An experimental histologic study. Acta Odontol Scand 1961;19:32453.

28. Schouten C, van den Beucken JJ, de Jonge LT, Bronkhorst EM, Meijer GJ, Spauwen PH, et al. The effect of alkaline phosphatase coated onto titanium alloys on bone responses in rats. Biomaterials 2009;30:6407-6417.

29. Denhardt DT, Noda M, O'Regan AW, Pavlin D, Berman JS. Osteopontin as a means to cope with environmental insults: regulation of inflammation, tissue remodeling, and cell survival. J Clin Invest 2001;107:1055-1061.

30. Barreiros D, Nelson P Filho, Paula-Silva FWG, Oliveira KMH, Lucisano MP, Rossi A, et al. MMP2 and MMP9 are Associated with Apical Periodontitis Progression and Might be Modulated by TLR2 and MyD88. Braz Dent J 2018;29:43-47.

31. Jesus SF, Cohenca N, Romualdo PC, Nelson-Filho P, Queiroz AM, Sousa-Neto MDet al. Radiographic and Immunohistochemical Evaluation of Root Canal Treatment Using Different Irrigation Systems. Braz Dent J 2019;30:123-132. 